\title{
Willow vegetation filters for wastewater treatment and soil remediation combined with biomass production ${ }^{1}$
}

\author{
by Pär Aronsson ${ }^{2}$ and Kurth Perttu ${ }^{2}$
}

Vegetation filters of fast-growing trees such as willows and poplars are becoming important as an alternative to conventional treatment of wastewater and landfill leachate. Short-rotation willow coppice is a non-edible crop and has many of the requirements for a suitable vegetation filter. The filtering capacity (e.g., of nitrogen) is very high, and the crop promotes denitrification in the root zone. It has a highly selective uptake of heavy metals, especially cadmium, which enables remediation of contaminated soils. In addition, willows have a high evapotranspiration rate facilitating high loads, e.g., of polluted landfill leachate. Because of the pathogens present in municipal wastewater and sludge, special attention must be paid to storage and distribution of wastewater. In many cases vegetation filters are more cost-effective than conventional treatment methods and also facilitate recycling of valuable resources in society.

Key words: bioenergy, economics, heavy metals, landfill leachates, municipal wastewater, pathogens, Salix spp., sewage sludge, wood ash

Les filtres végétaux constitués d'espèces à croissance rapide comme les saules et les peupliers sont de plus en plus importants comme alternatives au traitement conventionnel des eaux usées et du lixiviat des sites d'enfouissement. Les rejets de souche de saule de courte rotation représente une récolte non-comestible et couvrent plusieurs des prérequis recherchés dans un filtre végétal. La capacité de filtration (p. ex., de l'azote) est très élevée, et la culture favorise la dénitrification de la zone racinaire. Ils tirent du sol de façon très sélective les métaux lourds, surtout le cadmium, ce qui permet la remédiation des sols contaminés. De plus, les saules ont un fort taux d'évapotranspiration ce qui permet des quantités élevées, p. ex., de lixiviat de site d'enfouissement pollué. Compte tenu des pathogènes présents dans les eaux usées municipales et les boues résiduaires, une attention spéciale doit être apportée à l'entreposage et à la distribution des eaux usées. Dans plusieurs cas, les filtres végétaux sont plus efficaces en terme de coût que les méthodes de traitement conventionnel et facilitent également le recyclage de ressources intéressantes pour la société.

Mots-clés : bioénergie, économie, métaux lourds, lixiviat de site d'enfouissement, eaux usées municipales, pathogènes, Salix spp., boue résiduaire, cendre de bois

\section{Introduction}

\section{Background}

In the late 19th century, municipal waste problems were taken Seriously when the relationships between untreated or unsatisfactorily treated wastes and different diseases and infections were discovered. This problem was typically serious in urban areas, whereas in rural areas, the waste (i.e., sewage) was often used as a resource in agriculture. The ancient method of disposal of waste by "dumping" it in the streets was eventually abandoned in favour of collection and removal from the cities by sanitation workers. Large-scale introduction of toilets and sewage systems during the 20th century resulted in an efficient transport of sewage from the cities to the waterways. At first, this approach worked well and markedly brought down the outbreaks of diseases. However, it became apparent that these measures were not sufficient, and that more active methods of treating the wastewaters in special treatment plants were needed. The first approach was to remove as much as possible of the solid material using mechanical filters. The filtered debris was then deposited in landfills. Successively, this filtering was improved by an approach called "primary treatment." This approach involves an efficient removal of inorganic matter (sand, silt, gravel, etc.) as well as a sedimentation and/or flotation process to remove organic matter. A removal of 40 to $60 \%$ of the suspended solids and 20

\footnotetext{
${ }^{1}$ Presented to the 21st Session of the International Poplar Commission, September 24-28, 2000, Vancouver, Washington, USA.

${ }^{2}$ Swedish University of Agricultural Sciences (SLU), Department of Short Rotation Forestry, P.O. Box 7016, SE-75007 Uppsala, Sweden. E-mail: par.aronsson@lto.slu.se and kurth.perttu@1to.slu.se
}

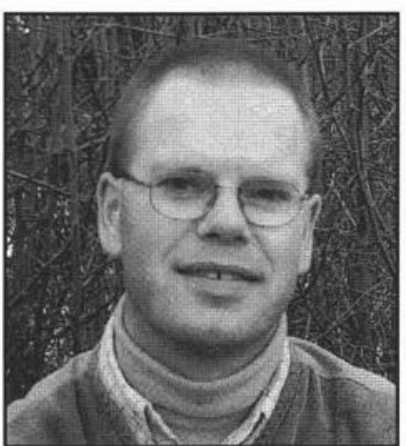

Pär Aronsson

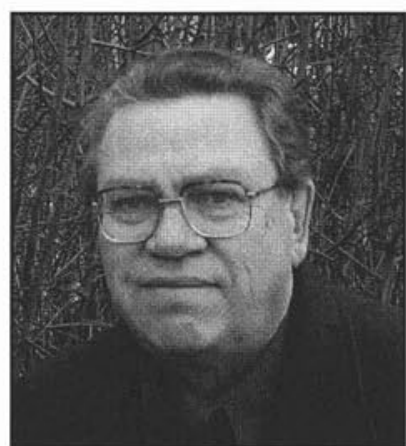

Kurth Perttu to $40 \%$ of the biochemical oxygen demand $\left(\mathrm{BOD}_{5}\right)$ is normally reached in this primary step (MS Encarta 96).

Continuing water quality problems, however, resulted in an additional requirement for "secondary treatment" of the wastewater. Using aeration, the microbiological decomposition of organic matter could be accelerated. For this, various methods, including trickling filters, activated sludge, and stabilisation ponds, were developed. With such methods, the content of organic matter in the effluent could be reduced by $60 \%$ to $85 \%$ (MS Encarta 96 ).

During the 1970s, "tertiary treatment" of the wastewater, i.e., phosphorus $(\mathrm{P})$ removal, was introduced in Sweden in order to counteract eutrophication of watercourses receiving sewage effluent. The resultant precipitated sludge can be used as a fertilizer in agriculture, but is often put in a landfill due to high concentrations of various pollutants, including heavy metals.

Severe eutrophication of coastal areas, especially the Baltic Sea, has led to the need for an even more efficient wastewater 
treatment (Anon. 1997). An "advanced wastewater treatment" involves not only the three steps mentioned but also additional steps to improve the quality of the effluents by further removal of nitrogen (N) (Nationalencyklopedin 1998). This improvement can be achieved using different methods, of which enhanced nitrification/denitrification is the most widely adopted (Balmér and Mattsson 1993).

Heavy metals, e.g., cadmium (Cd), lead (Pb) and chromium $(\mathrm{Cr})$ are found in most soils. Due to atmospheric deposition and the extensive use of contaminated $\mathrm{P}$ fertilizers, the content of many heavy metals has increased in arable soils (Eriksson 1999). In Sweden, Cd is regarded as the main problem in this context since it is taken up by food crops in amounts that may cause health problems (Notter 1993). There is discussion in Sweden of whether growing willows could be an efficient way of taking up heavy metals, which could then be redirected from the human food chain (Eriksson 1996). The work has been focused on $\mathrm{Cd}$, but screening for uptake and tolerance has been conducted for a large number of clones and heavy metals (Yasdani 1993).

\section{General comments and aim of the paper}

Since municipal wastes, especially wastewaters, can be regarded in many cases as resources rather than problems, there is increased interest in the use of wastewater for promotion of biomass production in natural systems (Aronsson and Perttu 1994, Hasselgren 1994, Reed et al. 1995). For sanitary reasons, the use of wastewater for irrigating edible crops needs utmost caution (Rose 1986). However, wastewater irrigation of crops grown for energy purposes or fibre production (e.g., willow coppice) can be performed with much less risk of causing human disease. In this context we have adopted "vegetation filters" as a soil-plant system used for remediation of waters and soils from different types of pollutants, including mineral nutrients, organic compounds, and heavy metals. The crop used as vegetation filters in Sweden consists mainly of different species of short-rotation willow coppice (SRWC) and sometimes poplars, alders and conifers. Different species and clones of willows (Salix viminalis, $S$. dasyclados and some new hybrids) have been shown to be efficient as vegetation filters with regard to nutrient and heavy metal uptake (Perttu and Kowalik 1997, Aronsson 2000). The filtering effect of the vegetation filters can then be combined with biomass production for energy purposes, thus producing renewable wood fuel for substitution of fossil fuels.

The objective of the present paper is to give an overall description of using short-rotation willow coppice as vegetation filter systems in terms of plant nutrient requirements, sanitary aspects and economics when treating municipal wastewater and sludge, and landfill leachates. We also discuss soil remediation using SRWC for removing Cd from the soil-plantsystem.

\section{Municipal waste treatment}

Wastewater treatment using vegetation filters of SRWC

Municipal wastewater can be efficiently treated and utilized in a vegetation filter system. The treatment method is widely adopted worldwide either as the only treatment or as a complement to conventional treatment (Crites 1984). If a vegetation filter system is used for polishing a pre-treated wastewater, such as after tertiary treatment, then the plant nutrient composition of the wastewater may be unfavourable. The optimal relationship among plant nutrients for willows (also valid for most green plants) is presented in Table 1 (Ericsson 1981). When comparing the plant requirements with the corresponding balance of different wastes it has been shown that untreated wastewater is highly suitable for willows (Table 2) (Perttu 1993). However, tertiary-treated wastewater, sewage sludge, and landfill leachates are more imbalanced from a plant nutrient point of view (Table 2).

At high northern latitudes as we have in Sweden $\left(>55^{\circ} \mathrm{N}\right)$, temperature is normally the most limiting factor for plant growth (Perttu 1983, Ledin and Perttu 1989). Therefore, growth is well correlated with the growing season temperature sums. With existing clonal material and management practices, growth rates in commercial Swedish SRWC rarely exceed 10 tonnes of dry matter per hectare per year. $\mathrm{N}$ and other plant nutrients are removed from the site through stem harvest, leaching to surface and ground waters, and gaseous losses. Assuming a N concentration of $0.5 \%$ and a growth rate of 10 tonnes, about $50 \mathrm{~kg} \mathrm{~N}$ per hectare per year is removed from the field by stem harvest. However, Aronsson (2000) has shown that the N-retention in a SRWC vegetation filter can usually be much higher. When denitrification and long-term binding of $\mathrm{N}$ in the soil are also considered, the retention capacity lies in the range of 100 to $200 \mathrm{~kg} \mathrm{~N}$ per hectare per year. Leaching losses of $\mathrm{N}$ from SRWC are usually negligible, which is interesting also from the perspective of decreasing the total leaching loads of $\mathrm{N}$ from arable land (Aronsson 2000). Thus, on each hectare of SRWC in southern Sweden, sewage from about 40 person equivalents (PE) could be treated. Due to freezing conditions, the wastewater produced during winter would have to be stored, adding additional costs for the vegetation filter method (see Economics of SRWC treatment, below). Under more favourable climate conditions, the cold season is shorter, plant growth is substantially higher, and consequently both demand and retention of plant nutrients are larger.

\section{Municipal sludge treatment using SRWC}

Conventional wastewater treatment plants produce considerable quantities of sludge that must be handled with care. There are strict regulations in many countries (Morsing 1994) concerning the use of sludge in agriculture and how the sludge has to be pretreated to decrease the hygienic risks (see Sanitary aspects of using SRWC as a vegetation filter, below). As shown in Table 2, municipal sludge has a strongly imbalanced nutrient composition compared to the optimal plant requirement. Therefore, dosing should not be based on the $\mathrm{N}$-composition alone. However, sludge is high in $\mathrm{P}$, also providing some organic $\mathrm{N}$ and humus to the soils. Cultivation of annual or semi-perennial crops often successively impoverishes arable soils, and the use of sludge as a fertilizer could counteract losses of organic matter. A problem in the use of sludge as a fertilizer is the presence of heavy metals, of which $\mathrm{Cd}$ is of most concern (see Soil remediation using SRWC, below). Moreover, stable organic compounds are usually also present in sludge. In Sweden, 5 to $10 \%$ of all sewage sludge is used as a fertilizer in SRWC. This approach is presently believed to be the "best" way of treating and utilizing municipal sludge. The main reason for this acceptance is that SRWC is a non-food crop, it is possible to control the flow of heavy metals in the system, and the long life-span of this crop (about 25 years) allows for the gradual degradation of potentially toxic organic compounds in the sludge. 
Table 1. Optimal relative proportions by weight of the nutrient compounds in a fertilizer for willow in relation to nitrogen N=100\% (Ericsson 1981 ).

\begin{tabular}{|c|c|c|c|c|c|}
\hline $\begin{array}{l}\text { Macronutrients } \\
\text { Name }\end{array}$ & Symbol & Proportion & $\begin{array}{l}\text { Micronutrients } \\
\text { Name }\end{array}$ & Symbol & Proportion \\
\hline Nitrogen & $\mathrm{N}$ & 100 & Iron & $\mathrm{Fe}$ & 0.6 \\
\hline Potassium & $\mathrm{K}$ & 72 & Manganese & $\mathrm{Mn}$ & 0.4 \\
\hline Phosphorus & $\mathrm{P}$ & 14 & Boron & B & 0.1 \\
\hline Sulphur & $\mathrm{S}$ & 9 & Zinc & $\mathrm{Zn}$ & 0.06 \\
\hline Magnesium & $\mathrm{Mg}$ & 8.5 & Copper & $\mathrm{Cu}$ & 0.03 \\
\hline \multirow[t]{3}{*}{ Calcium } & $\mathrm{Ca}$ & 7 & Molybdenum & Mo & 0.007 \\
\hline & & & Chlorine & $\mathrm{Cl}$ & 0.003 \\
\hline & & & Sodium & $\mathrm{Na}$ & 0.003 \\
\hline
\end{tabular}

Table 2. Comparison of the relative concentrations of the three macronutrients nitrogen $(\mathbf{N})$, phosphorus $(\mathbf{P})$ and potassium $(\mathrm{K})$ in the different municipal wastes in relation to nitrogen $\mathrm{N}=100$ (Perttu 1993).

\begin{tabular}{|c|c|c|c|c|c|}
\hline Element & $\begin{array}{l}\text { Optimum } \\
\text { composition } \\
\text { for SRWC }\end{array}$ & $\begin{array}{c}\text { Untreated } \\
\text { wastewater }\end{array}$ & $\begin{array}{c}\text { Tertiary treated } \\
\text { wastewater }(P \\
\text { reduced by } 75 \%)\end{array}$ & $\begin{array}{c}\text { Average } \\
\text { sludge in } \\
\text { Sweden }\end{array}$ & $\begin{array}{l}\text { Average landfil } \\
\text { leachate in } \\
\text { Sweden }\end{array}$ \\
\hline $\mathrm{N}$ & 100 & 100 & 100 & 100 & 100 \\
\hline K & 14 & 17.5 & $\approx 4.5$ & 73 & 0 \\
\hline
\end{tabular}

\section{Treatment of landfill leachates using SRWC}

Despite the overall efforts toward becoming a recycling sociస ety, landfills are still necessary for disposal of wastes. in Leachates from landfills result from precipitation, disposal of ¿liquid waste and water originating from biological and chemical processes within the landfill. Dissolving of various chemisal compounds of the material forms a solution that is often Environmentally hazardous. The composition of leachates to shanges with time, depending on the landfill construction, type aff waste deposited, and the ongoing processes. A wide specGum of wastes is normally disposed of in a landfill, and the E character of the generated leachates is highly variable. LandAnl leachates are in most cases unsuitable for direct discharge Tito waterways because of their high content of dissolved organic matter, ammonium $\left(\mathrm{NH}_{4}{ }^{+}\right)$, and their high ionic strength. The leachate problem accompanies landfills from their beginning until many decades or centuries after their closure. Landfill leachates are often treated in conventional wastewater treatment plants, but the overall treatment efficiency I may be disturbed by the leachates, and also the costs for such procedures are considerable. In addition, sewage sludge from wastewater treatment plants that are receiving landfill Ieachates is not allowed for use on farmland in Sweden. When implementing alternative treatment methods, vegetaII tion filters using SRWC have been shown to be of utmost importance (Roy 1999).

Normally, there are no intentions to restore a landfill, only to avoid the leachates from reaching and affecting the surrounding waterways in an uncontrolled way. Therefore, a method to decrease the net discharge of leachates from the landfill area would be sufficient and contain the hazardous compounds within the area. When using a vegetation filter, the landfill leachates must be collected and stored during the winter season and then used for irrigation of the plants during the growing season. With this method, plants must have a high evapotranspiration capacity, which is the case for willows (Persson 1995, Lindroth and Båth 1999). In addition, the plants must tolerate low oxygen levels in the root zone and a high ionic strength. In Sweden, there are more than 30 facilities where vegetation filters of SRWC are used for treatment of landfill leachates. The basic functions of such systems can be summarised as follows:

- Decreasing the leachate formation is accomplished by introducing a vegetative cap on sealed parts of the landfills. The evapotranspiration from a SRWC crop is substantially higher than from most other plant communities (Persson 1995).

- When irrigated with leachates (stored during winter) using sprinklers, evapotranspiration can be maximised by SRWC (Aronsson 1996) equalling annual precipitation in most climate regions of Europe, thus permitting no net discharge from the landfill area.

- $\quad$ Plants take up $\mathrm{N}$ and other elements in the leachates and facilitate transformation and binding of elements in the soil.

\section{Soil remediation using SRWC}

It became obvious in the early 1990s that some of the willow clones used in the Swedish SRWC programme were efficient in taking up $\mathrm{Cd}$, while others were not. This finding was important because the $\mathrm{Cd}$-accumulation in the southern Swedish arable topsoils since 1900 has been about $150 \mathrm{~g} \mathrm{Cd}$ per hectare (Notter 1993) and is still around $0.7 \mathrm{~g} \mathrm{Cd}$ per hectare per year according to Table 3 (Andersson 1992) except in the very last few years. Intake of $\mathrm{Cd}$ through food is believed to be a serious health problem and the prospect of decreasing the Cd-concentrations of arable soils, and thereby also in food, has resulted in substantial research efforts (Perttu et al. 2001). The following questions have been addressed:

- Is the redistribution of $\mathrm{Cd}$ from the subsoil to the topsoil of such a magnitude that problems may arise for future agricultural crops?

- Can high biomass production increase the Cd-uptake with better soil remediation as a result?

- How large an influence does the extent of $\mathrm{Cd}$ accumulation in the leaves have on the output and redistribution of $\mathrm{Cd}$ from subsoil to topsoil? 
Table 3. Annual average Cd-balance on southern Swedish farmland (Andersson 1992).

\begin{tabular}{llll}
\hline Input of Cd $\left(\mathrm{g} \mathrm{ha}^{\mathbf{- 1}} \mathbf{y r}^{\mathbf{- 1}}\right)$ & Output of Cd $\left(\mathrm{g} \mathrm{ha}^{\mathbf{- 1}} \mathbf{y r}^{\mathbf{- 1}}\right)$ \\
\hline Manure, commercial & \multicolumn{4}{c}{ Harvest products } \\
fertilizers, lime & 0.7 & (including straw) & 0.5 \\
Deposition & 0.6 & Leaching & 0.1 \\
Total input & 1.3 & Total output & 0.6 \\
\hline
\end{tabular}

- Will the Cd-content in the stumps be such a large problem that they must be removed after the final harvest, thus causing considerably higher costs compared to chopping them with a cutter and leaving them in the field?

The results of our research with SRWC show the following (Perttu et al. 2001):

- In most cases, there is only a relatively small amount of Cd redistributed from the subsoil to the topsoil in SRWC. This does not result in an accumulation of $\mathrm{Cd}$ in the topsoil, especially because the redistribution is always exceeded by the removal via stem harvest.

- It is possible to increase the Cd-uptake (and Cd-removal) with certain willow clones through optimisation of the stem production, especially if the concentration in the soil is high. When comparing different clones an optimisation of the combined effects of production capacity and uptake ability must be considered for the best remediation result.

- Through clonal selection, it is possible to maximize or minimize the Cd-transport to the aboveground plant components. There are clones that store relatively more $\mathrm{Cd}$ in the stems than in the leaves and vice versa (Landberg and Greger 1994).

- In commercial SRWC, it is not necessary to remove the stumps after the final harvest because $\mathrm{Cd}$ remains in them. Through stem harvest 30 to $320 \mathrm{~g} \mathrm{Cd}$ per hectare will be removed in each rotation period (normally 25 years), which exceeds the present net input of $\mathrm{Cd}$ of less than $20 \mathrm{~g}$ during the same period. However, if a more rapid soil remediation process is desirable, the Cd-removal can be increased by $10-35 \mathrm{~g}$ per hectare in each rotation period if the stumps are also removed. Notice that the variations are large, depending mainly on the clone used but also on the Cd-concentration and the $\mathrm{pH}$ of the soil.

\section{Sanitary aspects using SRWC as a vegetation filter}

A large number of species and strains of bacteria, parasites, and viruses may be present in domestic wastewater (Rose 1986, Bitton 1994). These organisms frequently contaminate drinking water, because of leaking sewage pipe systems or inadequately located septic tanks, enabling them to reach the groundwater (Keswick and Gerba 1980, Stenström 1996). Once they reach the groundwater, they can survive for long periods and viruses can be transported long distances, i.e., several hundred metres (Schaub and Sorber 1977, Yates and Yates 1988, Sinton et al. 1997). Therefore, when using domestic wastewater for irrigation of crops, the risk of harmful micro-organisms reaching the groundwater must be considered. Bacteria and parasites are in most cases efficiently filtered out in a soil, or a constructed sand medium due to their large size, whereas viruses have been found to be more mobile in the same conditions (Keswick and Gerba 1980, Jansons et al. 1989, Bitton
Table 4. Economic comparison between conventional methods and vegetation filter systems for wastewater treatment in Sweden (Rosenqvisi et al. 1997). The costs are recalculated to US\$ using a rate of 1 US\$ = 9 SEK.

\begin{tabular}{|c|c|}
\hline Average & ost US\$ $(\mathrm{kg} \mathrm{N})^{-1}$ \\
\hline Conventional $\mathrm{P}$ treatment during whole year & $4.5-9$ \\
\hline Conventional $\mathrm{P}$ and $\mathrm{N}$ treatment during whole year & $8-20$ \\
\hline Vegetation filter treatment during summer (6 month) & \\
\hline plus conventional $\mathrm{P}$ treatment during winter ( 6 month) & $6-10.5$ \\
\hline $\begin{array}{l}\text { Vegetation filter treatment during summer ( } 6 \text { month) } \\
\text { plus conventional } \mathrm{P} \text { and } \mathrm{N} \text { treatment during }\end{array}$ & \\
\hline winter ( 6 month) & $8-19$ \\
\hline Vegetation filter treatment during summer ( 6 month) & \\
\hline plus storage of wastewater during winter ( 6 month) & $10-13$ \\
\hline
\end{tabular}

1994). Viruses are also of special concern because of the low dose needed for infection, often as low as 1 to 10 virus particles (Rose 1986). Therefore, wastewater irrigation should be avoided in groundwater recharge areas if the groundwater is used for human consumption. Viruses can be efficiently retained on sandy, non-structured soils, permitting safe wastewater irrigation (Carlander et al. 2000). Conventional sprinkler irrigation systems are highly unsuitable due to the risk of spreading pathogens by aerosols. Instead, drip irrigation flooding or low-pressure and low-mounted sprinklers car be used.

\section{Economics of SRWC treatment}

During the past decade, regulations requiring $\mathrm{N}$ removal from wastewaters have resulted in substantial efforts and investments in Sweden. In some places, vegetation filter systems have beer adopted instead of more expensive conventional advancec treatment methods. An economic comparison between a conventional treatment method and a vegetation filter system was presented by Rosenqvist et al. (1997). The comparison was made for a number of different options, depending on the pre. requisites and investment needs, and for relatively smal (200 to 2000 PE) municipalities.

The alternatives studied included: i) conventional $\mathrm{P}$ or $\mathrm{P}$ anc $\mathrm{N}$ treatment during the whole year, ii) conventional $\mathrm{P}$ or $\mathrm{P}$ anc $\mathrm{N}$ treatment during the winter season combined with vegeta. tion filter (SRWC) during the growing season (here pre sumed to be six months), and iii) vegetation filter treatmen with SRWC including storage for six months in constructec ponds. The results showed that the costs for conventional $\mathrm{F}$ and $\mathrm{P}+\mathrm{N}$ treatments lie between 4.5 to 9 and 8 to 20 US\$ pe: $\mathrm{kg} \mathrm{N}$, respectively (Table 4$)^{3}$. The higher values include ful investment costs for tertiary and advanced treatment, while the lower values presuppose only smaller modifications of exist ing facilities. The costs for the vegetation filter system (includ ing investment, operational, and capital costs) vary betweet 10 and 13 US\$ per $\mathrm{kg} \mathrm{N}$ for the whole year option (storage dur ing winter) and between 6 to 10.5 and 8 to 19 US\$ per $\mathrm{kg} \mathrm{N}$ for the combined alternatives. Note that the costs are recalculater on the basis of $\mathrm{N}$ removal. Thus, a vegetation filter system ir Sweden can compete well economically with conventional advanced $\mathrm{N}$ treatment. Sensitivity analyses showed that, fo instance, the dosing of wastewater greatly affects the costs, anc that high doses permit lower investment costs for irrigation pipes

\footnotetext{
${ }^{3}$ Conversion from Swedish to US currency, 1 US $\$=9$ SEK
} 
Table 5. Economic comparison between municipal sludge distribution ( 5 tonnes dry weight per hectare) on farmland and deposition in a landfill (Hahn 1992). The sums are recalculated to US $\$$ using a rate of 1 US $\$=9$ SEK.

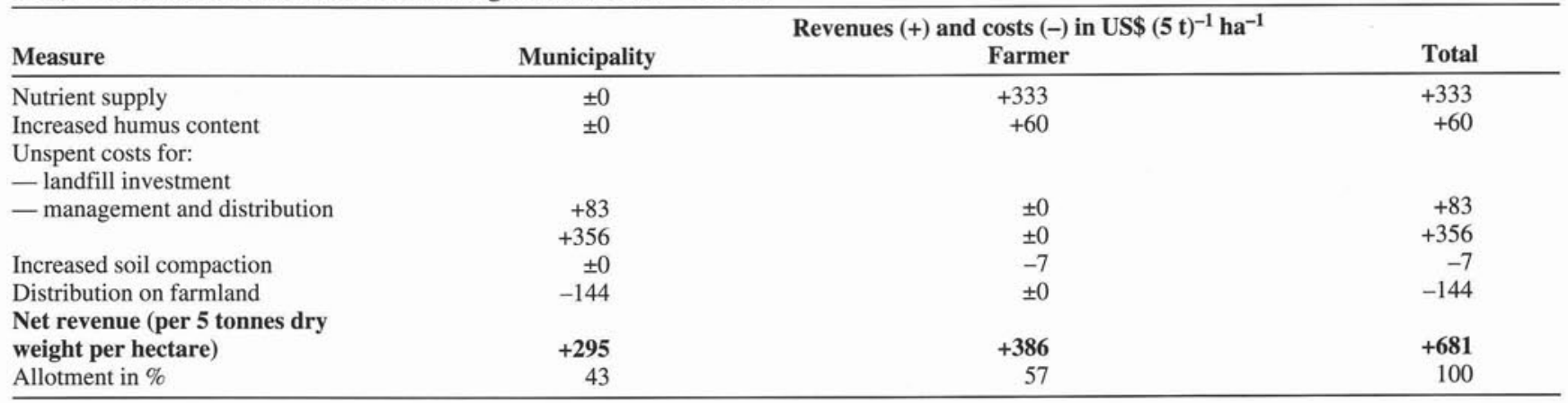

Table 6. Economic comparison between distribution of bio-fuel ash on farmland (dose 1 dry tonne per hectare) and deposition on landfill (Vattenfall 1992). The sums are recalculated to US $\$$ using a rate of 1 US $\$=9$ SEK.

\begin{tabular}{lccc}
\hline Measure & Municipality & Revenues (+) and costs (-) in US\$ t & Farmer \\
Fertilizer value (N is lacking) & \pm 0 & +100 & Total \\
Management and deposition & +30 & \pm 0 & +100 \\
Granulation, packing, transport and distribution & \pm 0 & -73 & +30 \\
Net revenue (per tonne dry matter) & $+\mathbf{3 0}$ & +27 & -73 \\
Allotment in \% & 53 & 47 & $+\mathbf{5 7}$ \\
\hline
\end{tabular}

Similarly, there are lower costs for treating wastewater with high $\mathrm{N}$-concentration than with low. The calculations presumed that irrigation with wastewater would increase the biomass production by about 2 tonnes dry matter per hectare per year. This Yestimate was for the southern third of Sweden, but in regions where rain is more of a limiting factor, the biomass producion might increase more.

When using municipal sludge instead of wastewater, there are also several advantages, even if the positive effect of water on productivity is lacking. A study by Hahn (1992) shows that when sludge is treated and utilized in SRWC compared to depositing it in a landfill, it is economically favourable both for the municipality and the farmer (Table 5). The total revenue of applying 5 tonnes of sludge (dry weight) per hectare is almost 700 US\$; in Sweden it would be split $43 / 57 \%$ between the municipality and farmer.

The use of ash from bio-fuel combustion as a fertilizer on arable, peat or forested land is also favourable for the municipality and the landowner (Vattenfall 1992). Table 6 shows that, compared with deposition on landfills, spreading of one tonne of ash (dry weight) on the types of land mentioned above can give a total revenue of about 60 US\$ per tonne, again in Sweden split $53 / 47 \%$ between the municipality and farmer.

\section{Relevant research on vegetation filters}

In Sweden, the research concerning vegetation filters of SRWC has been focused on $\mathrm{N}$-retention and $\mathrm{N}$-transformation and on sanitary aspects. The results show that the $\mathrm{N}$-leaching from wastewater-irrigated willow vegetation filters can be very high during the establishment phase, i.e., the year of planting (Aronsson 2000, Aronsson et al. 2000). Thus, during the establishment, neither wastewater nor commercial fertilizers should be applied to the crop. However, once established, Nleaching from willow vegetation filters is low, permitting high inputs of N-rich wastewater. Within reasonable limits, the N- leaching is independent of irrigation rates and, thus, dosing of wastewater should be based on $\mathrm{N}$-loads. The $\mathrm{N}$-retention in a willow vegetation filter (up to about $200 \mathrm{~kg} \mathrm{~N}$ per ha per year) is due to plant uptake and incorporation into woody tissues (including harvestable shoots), and to a build-up of the organic matter pool in the soil. In addition, gaseous N-losses primarily due to denitrification are substantial.

The sanitary risk of using wastewater for irrigation of SRWC has been studied from the point of view of groundwater contamination by viruses (Aronsson 2000, Carlander et al. 2000). Preferential flow of water in cracks and fissures can accelerate the transport of viruses applied to a structured clay soil, and viruses may reach the groundwater within a few hours. However, viruses are efficiently retained in a sandy, non-structured soil, mainly as a result of strong electrostatic interaction between viruses and soil colloids. A number of studies concerning zoonotic (i.e., via animals) transfer of pathogens have been performed but remain to be reported.

\section{Full-scale vegetation filter systems in Sweden}

There are presently more than 40 vegetation filter systems with SRWC in Sweden (Roy 1999). Most of these systems are designed for treatment of landfill leachates, but there are four large $(>10 \mathrm{ha})$ systems for wastewater treatment. One of these is a 76-ha system designed for treatment of supernatant from dewatering of sewage sludge. In the latter system, about $25000 \mathrm{~m}^{3}$ of supernatant containing some $20000 \mathrm{~kg} \mathrm{~N}$ will be treated. The very high $\mathrm{N}$-concentration of the supernatant (in the order of $800 \mathrm{mg} \mathrm{N}$ per litre) allows for low-cost storage during winter, making the vegetation filter system considerably less expensive than conventional engineered systems.

\section{Conclusions and perspectives}

From our experience and results to date, the following conclusions can be made: 
- Nitrogen leaching from conventional SRWC is minimal and an extensive cropping of SRWC would decrease the nitrogen leaching to waterways and groundwater.

- SRWC vegetation filters are efficient in taking up nutrients from wastewater. The production in stands irrigated with wastewater is expected to be higher than in conventionally managed stands, depending on the fertilisation effect, and on the irrigation effect. The wastewater should be distributed using drip irrigation, flooding, or lowpressure, low-mounted sprinklers to avoid aerosol spreading of pathogens.

- Municipal sludge can be used as fertilizer for SRWC. This approach is probably one of the "best" ways to utilise sludge without the risk of different toxic compounds entering the human food chain.

- $\quad$ SRWC can be used as vegetation filters for treatment of municipal landfill leachates. The main objective of such treatment is not to purify the leachates, but rather to keep the pollutants within the landfill area by increased evapotranspiration.

- Vegetation filters of SRWC can be used for soil remediation, especially with cadmium (Cd). A net removal of up to $12 \mathrm{~g}$ Cd per ha per year has been achieved in the Swedish studies. However, Cd-rich wood ashes must be handled with caution in order not to release the Cd back into the environment.

- Treatment of wastewater, sludge and leachates using vegetation filters of SRWC can compete economically with conventional treatment in Sweden.

\section{Acknowledgements}

Financial support was given by the Swedish Farmers Foundation for Agricultural Research (SLF), the Swedish National Board for Industrial and Technical Development (NUTEK), the Swedish National Energy Administration (STEM), and Vattenfall AB. Dr. Jud Isebrands and Prof. Louis Zsuffa have reviewed the manuscript. We want to cordially thank these organisations and persons for their support and constructive comments.

\section{References}

Andersson, A. 1992. Trace elements in agricultural soils - fluxes, balances and background values. Swedish Environmental Protection Agency, Stockholm. Report 4077.

Anon. 1997. Kväve från land till hav - Huvudrapport (Nitrogen from land to sea - Main report). Swedish Environmental Protection Agency, Stockholm, Report 4735. (in Swedish)

Aronsson, P. 1996. Simulated evapotranspiration from a landfill irrigated with landfill leachates. In Perttu and Koppel (eds.). Short Rotation willow coppice for renewable energy and improved environment. Report 57, Dept. of Short Rotation Forestry, Swed. Univ. Agric. Sci. pp. 167-172. Uppsala, Sweden.

Aronsson, P. 2000. Nitrogen Retention in Vegetation Filters of Short-Rotation Willow Coppice. Doctoral thesis. Silvestria 161. Swed. Univ. Agric. Sci., Uppsala, Sweden.

Aronsson, P.G., L.F. Bergström and S.N.E. Elowson. 2000. Long-term influence of intensively cultured short-rotation willow coppice on nitrogen concentrations in groundwater. Journal of Environmental Management 58: 135-145.

Aronsson, P. and K. Perttu (eds.). 1994. Willow vegetation filters for municipal wastewaters and sludges. A biological purification system. Dept. of Ecology and Environmental Research, Swed. Univ. Agric. Sci., Uppsala, Sweden. Report 50, 230 p.
Balmér, P. and B. Mattsson. 1993. Kostnader för drift av avlopp sreningsverk (Costs for running of wastewater treatment plants) VAV/VA-FORSK, Stockholm. Rapport 1993-15.

Bitton, G. 1994. Wastewater Microbiology. Wiley-Liss, New York Carlander, A., P. Aronsson, G. Allestam, T.A. Stenström and K Perttu. 2000. Transport and retention of bacteriophages in twi types of willow-cropped lysimeters. Journal of Environmental Sci ence and Health 35(8): 1477-1492.

Crites, R.W. 1984. Land use of wastewater and sludge. Environ. Sci Technol. 18: 140-147.

Ericsson, T. 1981. Growth and nutrition of three Salix clones in lov conductivity solutions. Physiologia Plantarum 52: 239-244.

Eriksson, J. 1996. Kan Salixodling rena marken från kadmium? (Ca) growing of willows reduce the soil cadmium content?). In A. Görans son (ed.). Salix som kadmiumfilter (Salix as cadmium filter). Dept of Short Rotation Forestry, Swed. Univ. Agric. Sci., Uppsala. Repor 55: 75-82. (in Swedish)

Eriksson, J. 1999. Kadmium i jordbruksmark och gröda (Cadmiun in arable soils and crops). In Perttu and Göransson (eds.). Kadmi um i jordbrukssamhället (Cadmium in the agricultural society) Dept. of Short Rotation Forestry, Swed. Univ. Agric. Sci., Uppsala Report 65: 17-26. (in Swedish)

Hahn, T. 1992. Sewage sludge on farmland or landfill? Economic consequences for municipalities and farmers. Swed. Univ. Agric. Sci. Uppsala, Fakta Ekonomi No. 1. 4 p. (in Swedish)

Hasselgren, K. 1994. Kågeröd wastewater recycling experiment. Ir P. Aronsson and K. Perttu (eds.). Willow vegetation filters fo: municipal wastewaters and sludges. A biological purification system Dept. of Short Rotation Forestry, Swed. Univ. Agric. Sci., Uppsala Report 50: 207.

Jansons, J.J., L.W. Edmonds, B. Speight, and M.R. Bucens 1989. Movement of viruses after artificial recharge. Water Res. 23 293-299.

Keswick, B.H. and C.P. Gerba. 1980. Viruses in groundwater. Env. iron. Sci. Technol. 14: 1290-1297.

Landberg, T. and M. Greger. 1994. Can heavy metal toleran clones of Salix be used as vegetation filters on heavy metal contaminatec land? In P. Aronsson and K. Perttu (eds.). Willow vegetation filters for municipal wastewaters and sludges. A biological purification sys. tem. Dept. of Short Rotation Forestry, Swed. Univ. Agric. Sci. Uppsala. Report 50: 133-144.

Ledin, S. and K.L. Perttu. 1989. Climatic, edaphic and managemen requirements for energy forestry. In K.L. Perttu and P.J. Kowalik (eds.) Modelling of energy forestry. Growth, water relations and economics. Simulation Monographs 30: 3-11, Pudoc, Wageningen Netherlands.

Lindroth, A. and A, Båth. 1999. Assessment of regional willow coppice yield in Sweden on basis of water availability. Forest Ecology and Management 121: 57-65.

Morsing, M. 1994. The use of sludge in forestry and agriculture. A comparison of the legislation in different countries. Danish Fores 1 and Landscape Research Institute, The Royal Veterinary and Agricultural University, Forskningsserien Nr. 5. 66 p.

MS Encarta. 1996. Sewage Disposal. Microsoft Encarta 96 Encyclopedia on CD-ROM.

Nationalencyklopedin. 1998. (National Encyclopedia 1998), Bokförlaget Bra Böcker AB, Multimedia, Höganäs, Sweden. (in Swedish) Notter, M. 1993. Metallerna och miljön (Metals and environment). Swedish Environmental Protection Agency, Stockholm. Report 4135. (in Swedish)

Persson, G. 1995. Water balance of willow stands in Sweden. Doctoral thesis. Reports and dissertations 20. Dept. of Soil Sciences, Swed. Univ. Agric. Sci., Uppsala, Sweden.

Perttu, K.L. 1983. Temperature restraints on energy forestry in Sweden. Intern. J. Biometeor. 27(3): 189-196.

Perttu, K.L. 1993. Biomass production and nutrient removal from municipal wastes using willow vegetation filters. Journal of Sustainable Forestry 1(3): 57-70. 
Perttu, K., J. Eriksson, M. Greger, A. Göransson, K. Blombäck, E. Klang-Westin, and T. Landberg. 2001. Förråd och flöden av kadmium i systemet mark-Salix (Storage and fluxes of cadmium in the soil-willow-system). Dept. of Short Rotation Forestry, Swed. Univ. Agric. Sci., Uppsala. (in Swedish)

Perttu, K.L. and P.J. Kowalik. 1997. Salix vegetation filters for purification of waters and soils. Biomass \& Bioenergy 12(1): 9-19.

Reed, S.C., R.W. Crites, and E.J. Middlebrooks. 1995. Natural systems for waste management and treatment. McGraw-Hill, Inc., 2nd edition, New York, Toronto. 434 p.

Rose, J.B. 1986. Microbial aspects of wastewater reuse for irrigation. Crit. Rev. Environ. Control 16: 231-256.

Rosenqvist, H., P. Aronsson, K. Hasselgren, and K. Perttu. 1997. Economics of using municipal wastewater irrigation of willow coppice crops. Biomass \& Bioenergy 12(1): 1-8.

Roy, D. 1999. Lokal lakvattenbehandling i mark-växt-system (Local leachate treatment in soil-plant-system). Masters Thesis, Lund Institute of Technology. (in Swedish)

Schaub, S.A. and C.A. Sorber. 1977. Virus and bacterial removal from wastewater by rapid infiltration through soil. Appl. Environ. Microbiol. 33: 609-619.
Sinton, L.W., R.K. Finlay, L. Pang, and D.M. Scott. 1997. Transport of bacteria and bacteriophages in irrigated effluent into and through an alluvial gravel aquifer. Water, Air and Soil Pollution 98: 17-42. Stenström, T.-A. 1996. Sjukdomsframkallande mikroorganismer i avloppssystem - Riskvärdering av traditionella och alternativa avloppslösningar (Disease-causing micro-organisms in sewage systems - Risk assessment of traditional and alternative solutions). Swedish Environmental Protection Agency, Stockholm. Report 4683. (in Swedish)

Vattenfall. 1992. Sewage sludge and ash in growing energy crops. Vattenfall AB, Stockholm, Bioenergi U(B), 1992/12. 77 p.

Yasdani, R. 1993. Genetisk variation och nedärvning av metall- och tungmetalltolerans hos Salix viminalis (Genetic variation and heredity of metal and heavy metal tolerance in Salix viminalis). In K. Perttu (ed.). Energiskog som vegetationsfilter för slam, avloppsvatten, lakvatten och aska. Rapport från seminarium den 14 november 1991, Ultuna, Uppsala. Dept. of Short Rotation Forestry, Swed. Univ. Agric. Sci., Uppsala, Report 47: 59-67, 2nd edition. (in Swedish)

Yates, M.V. and S.R. Yates. 1988. Virus survival and transport in ground water. Water Sci. Technol. 20: 301-307. 